\title{
Chapter 6 \\ Bluefin Tuna Fishing in the Bay of Biscay
}

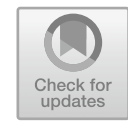

\begin{abstract}
The traditional fishing method for catching bluefin tuna in the Bay of Biscay used to be trolling, but in 1949 rod and live bait (bait boat) was introduced, which meant a great leap forward in the catches of this species. The different phases of fishing with this new system are briefly described as well how the fleet developed from the middle of the 20th century and the fishing seasons and type of fishes caught in this fishery.
\end{abstract}

\subsection{History}

Up until the middle of the 20th century ABFT was mainly caught in the Bay of Biscay by trolling (Fig. 6.1), but from 1947 a great transformation took place when the first test was made with bait boat thanks to the initiative of the shipowners of St-Jeande-Luz (France), G. Pommereau and A. Elissalt, who had seen this fishing modality used by Japanese and North American fishermen in the Pacific Ocean targeting tuna (De la Tourrase 1951).

The Basque fishing vessels Marie Elisabeth and La Nivelle, based at the port of Ciboure (France), were the first to try out ABFT fishing with rods and live bait in 1947 (Anonymous 2008). This new system was an important development in the region as it significantly increased the possibilities of exploiting ABFT, making it possible to catch even the largest fishes using rods, and doing so in great quantities.

This new way of catching ABFT quickly crossed the border and by 1949 Spanish fishermen had already adopted it. At first wooden bait tanks were installed on deck. The water was renewed constantly ( 8 times/h) by a pump driven by the ship's engine. By 1954 all of the bait tanks were metallic and were built inside the hull to form part of the structure of the vessel and had a circulation system independent of the main engine.

The fleet targeting ABFT in the 1950s was made up of around 120 vessels, from S. Jean de Luz, Hendaye and Fuenterrabía (Hondarribia) although vessels from other ports dedicated to albacore tuna, Thunnus alalunga (Bonn.), also caught ABFT (De la Tourrase 1951); hence, in that decade record catches were reached, the consequences of which are studied in later chapters. 


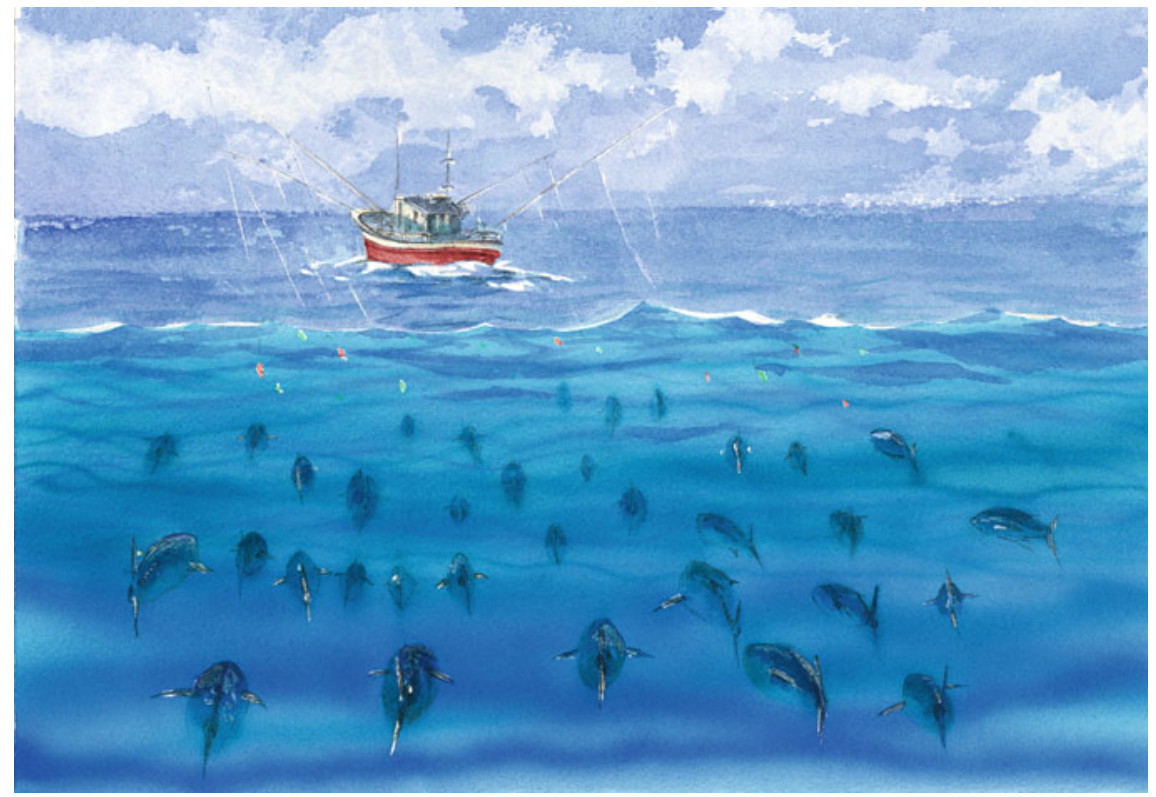

Fig. 6.1 Fishing with trolling An interpretation by Cort (2007) Artist: Lineke Zubieta (Santander, Spain) (Documentary archive, IEO)

In 1957 and 1958 the first echo sounders were installed, but the greatest advance came in the 1970s when most vessels installed radar and sonar. This latter provided great advantages to surface fishing.

In the 1960s the bait boat fleet of both Spain and France was made up of around 70 vessels; by the 1990s there were barely 20 (Cort 1990). There are now 15 modern vessels remaining in Spain (Fig. 6.2), equipped with the latest navigation and fishing equipments (Santiago et al. 2012). In France, however, just one remains, as bait boat was replaced by pelagic trawl from the 1990s. It must also be remembered that in the coastal ports of the Cantanbrian Sea that target albacore tuna, ABFT is also taken as a by-catch.

\subsection{The Fishing Itself}

The first operation consists of catching the live bait, which is done using purse seine nets. The bait species collected are mainly horse mackerel, Trachurus trachurus (L.); bogue, Boops boops (L.); sardine, Sardina pilchardus (Walbaum), and anchovy, Engraulis encrasicholus (L.). Fishes are put into the tanks (Fig. 6.3), which are filled before ABFT fishing begins. 


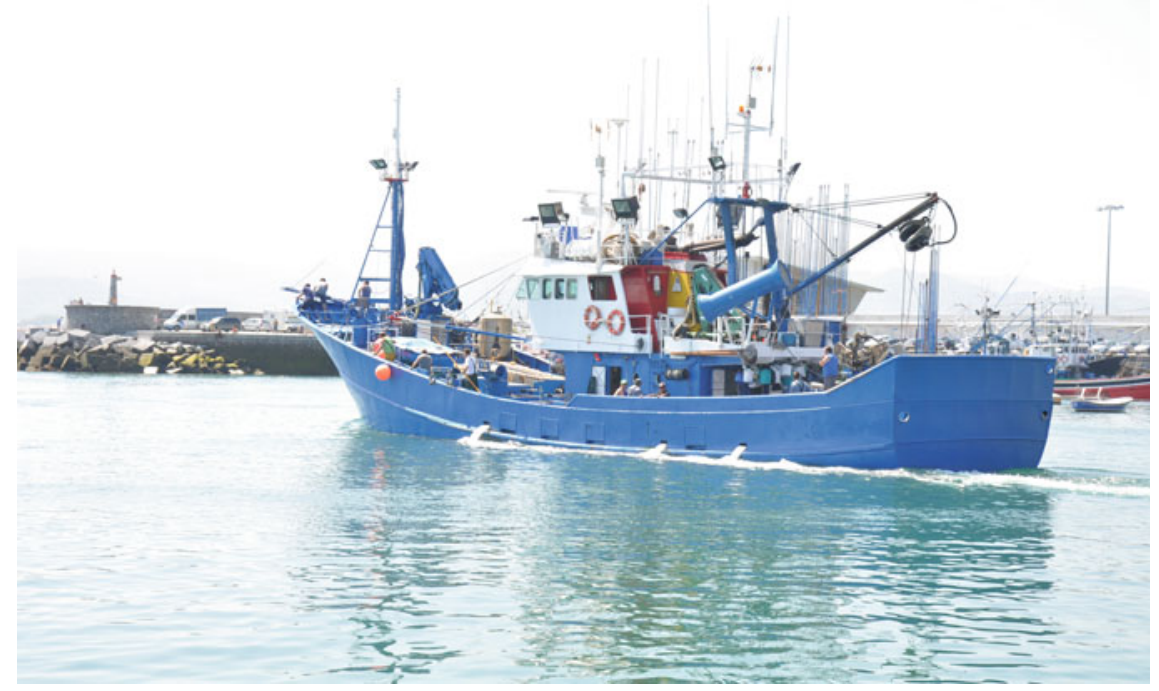

Fig. 6.2 Madre Guadalupe, modern fishing vessel in Hondarribia (2009) (Documentary archive, IEO)

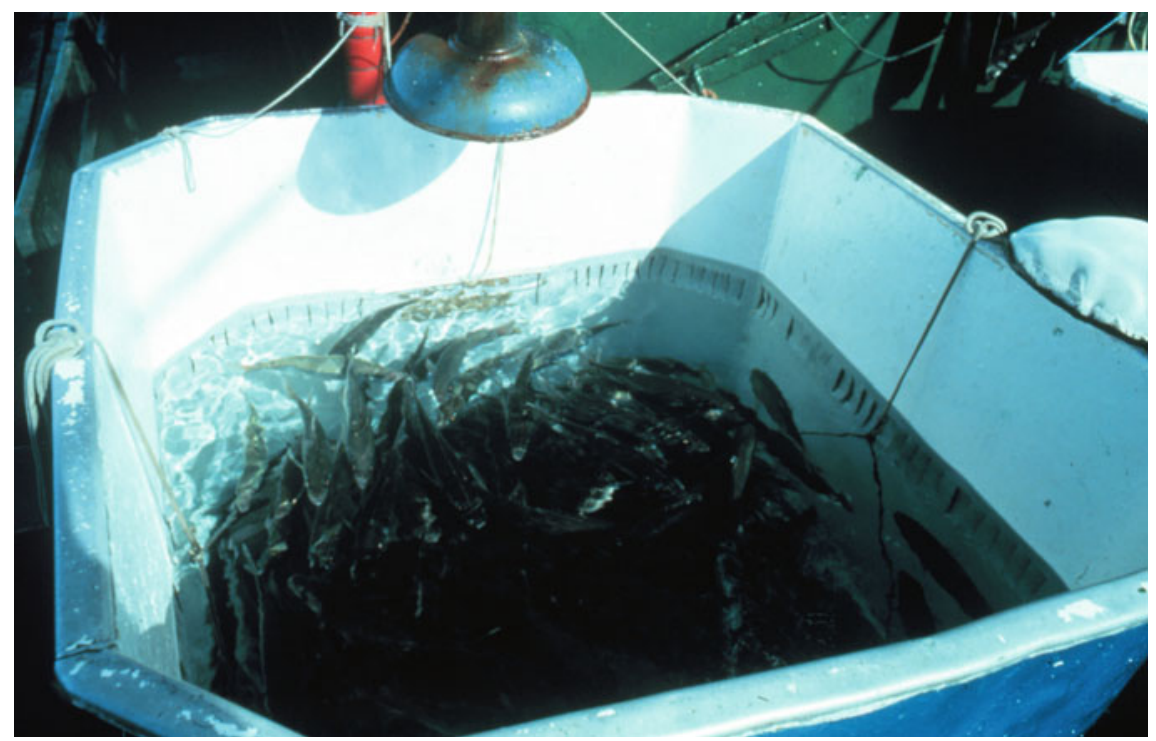

Fig. 6.3 Tank with live bait (http://www.photolib.noaa.gov/bigs/fish2034.jpg) (Documentary archive, IEO) 


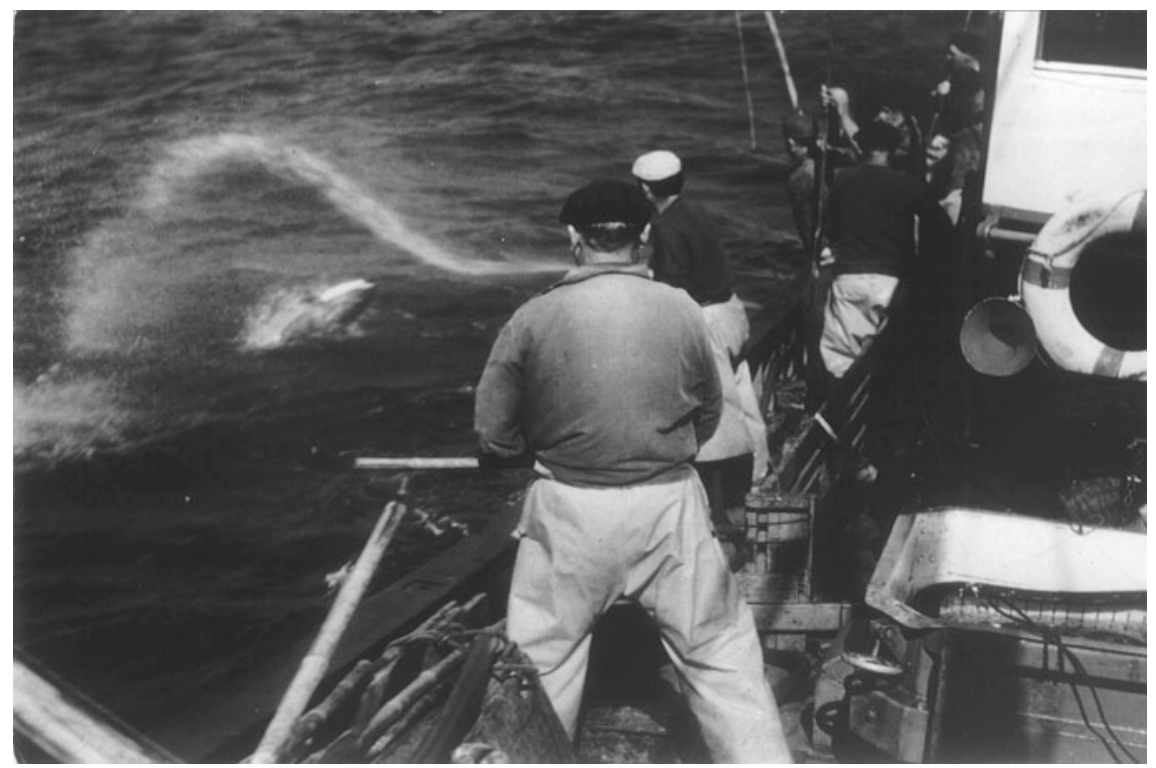

Fig. 6.4 Fishing for bluefin tuna using pole and live bait. Bay of Biscay (1958) (Photograph, E. Ithurria) (http://www.photolib.noaa.gov/bigs/fish2083.jpg) (Documentary archive, IEO)

When the bait boat fishery began in the 1950s fish were caught using rods (Fig. 6.4) or reels (Figs. 6.5a, b). Reels were used mainly in the fishing season of large specimens, which were caught one by one with the boat stationary. Once the bank of these fishes had been located the boat stopped over it and by baiting it fishing could continue for one or several days until the hold was full. Lateral watering was used in this fishery and the live bait was thrown into attract the ABFT.
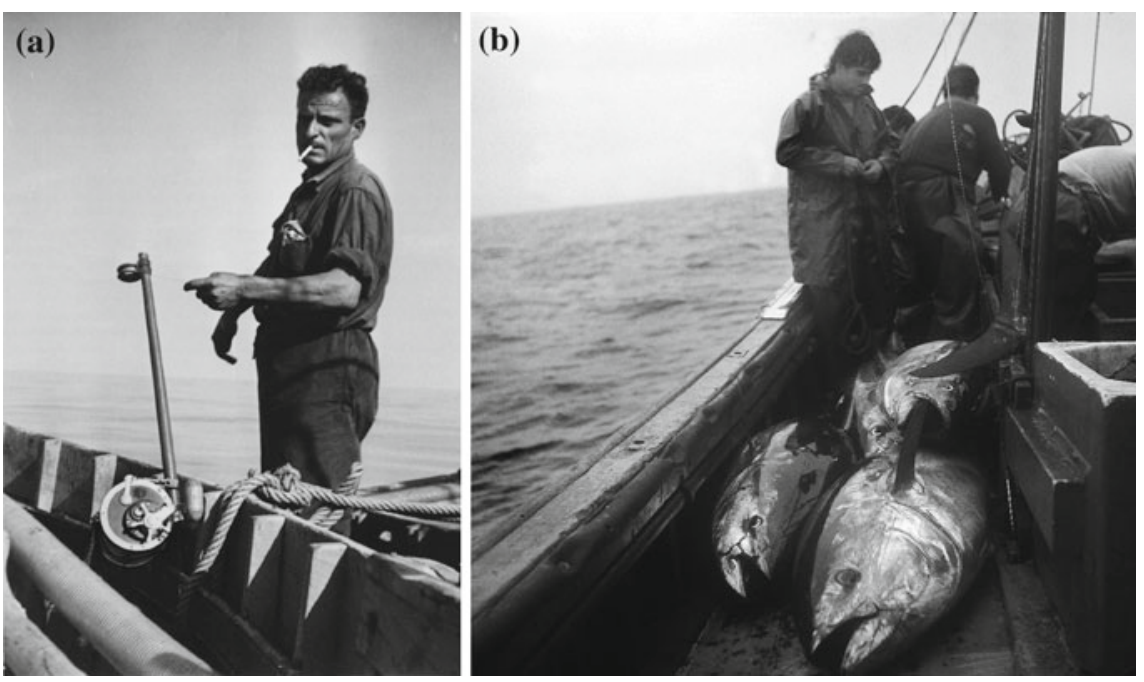

Fig. 6.5 (a) Reel (http://www.photolib.noaa.gov/bigs/fish2079.jpg) (Documentary archive, IEO). (b) Fishing with reel and live bait (Documentary archive, IEO) 


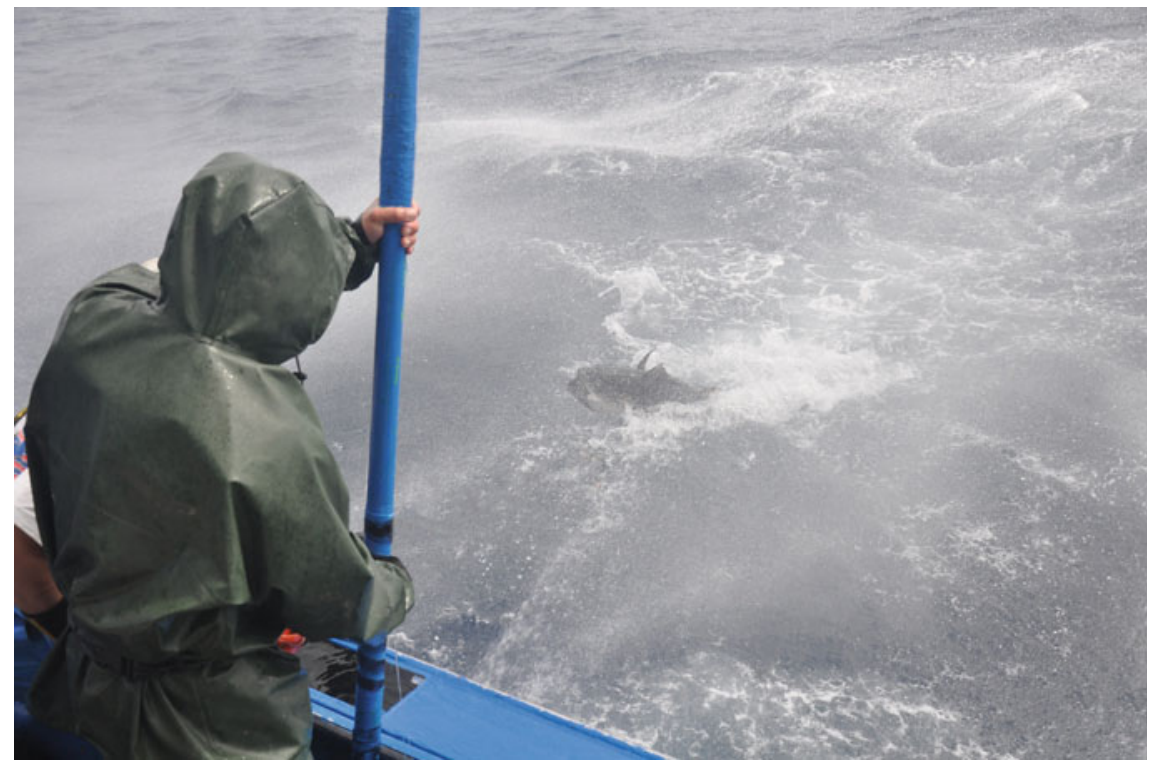

Fig. 6.6 Catching a small bluefin tuna spawner (> $40 \mathrm{~kg}$ ) using a pole and live bait (2009) (Documentary archive, IEO)

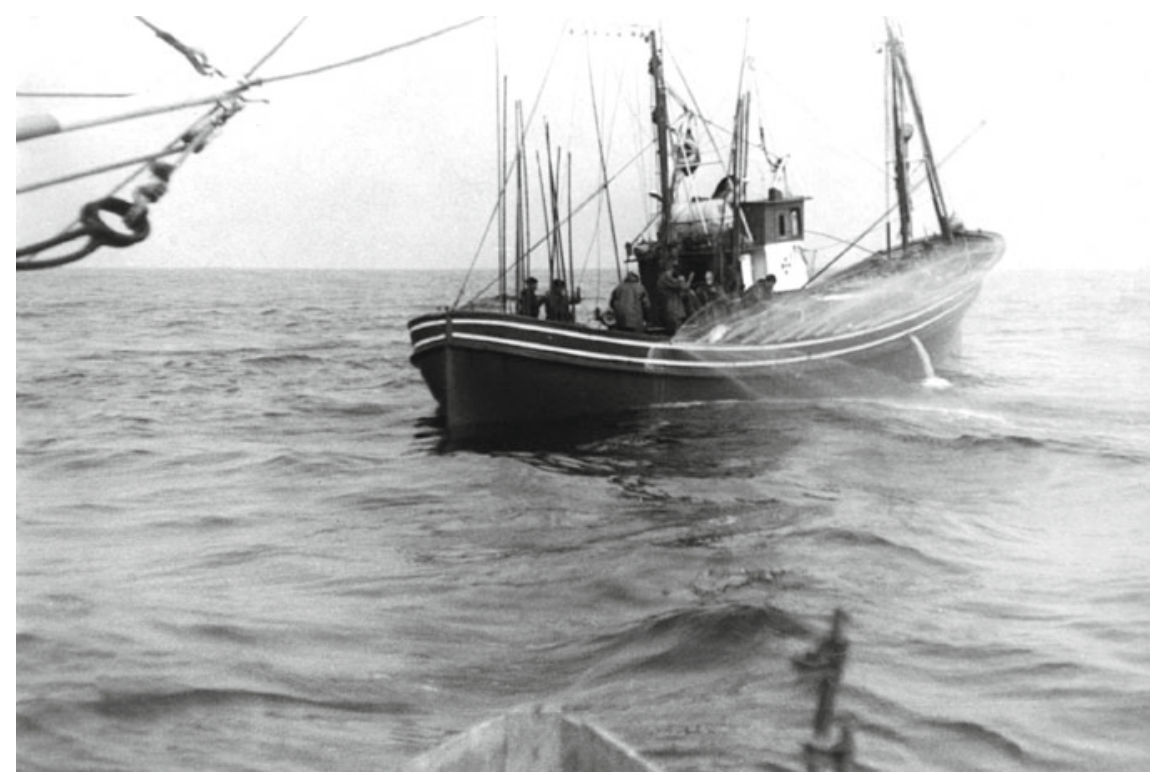

Fig. 6.7 Spanish bait boat fishing bluefin tuna in the Bay of Biscay (1972) (http://www.photolib. noaa.gov/bigs/fish2063.jpg) (Documentary archive, IEO) 
Over time this fishing method disappeared and nowadays whenever these spawners are targeted rods are used with the boat moving forward (Fig. 6.6).

The Bay of Biscay is an area of trophic concentration of ABFT. It is a seasonal fishery that lasts from June to October and is made up of juveniles aged 1-4 (5-30 kg) and small spawners of 5-10 years $(40-150 \mathrm{~kg}$ ) whose stay is generally shorter than the juveniles. They are more common in July and August (Fig. 6.7).

\section{References}

Anonymous (2008) La revolution du port, le thon à la canne. Altxa Mutillak 9(10):28-31

Cort JL (1990) Biología y pesca del atún rojo, Thunnus thynnus (L.), del mar Cantábrico. Doctoral thesis. Publicaciones especiales, IEO, vol 4, 272 pp.

Cort JL (2007) El enigma del atún rojo reproductor del Atlántico nororiental. Modalidad, Sosteni bilidad. Octavo concurso nacional de Ciencia en Acción. José L. Cort (coordinador). Instituto Español de Oceanografía. Depósito legal: SA. 538-2007, 62 pp.

De la Tourrase G (1951) La pêche aux thons sur la côte basque française et son evolution récente. Rev Trav Off Pêches Mari Tome 18, fas. 1, 66, 42 pp.

Santiago JH, Arrizabalaga, Ortiz M (2012) Standardized CPUE index of the Bay of Biscay baitboat fishery (1952-2011). ICCAT-SCRS/2012/100

Open Access This chapter is licensed under the terms of the Creative Commons Attribution 4.0 International License (http://creativecommons.org/licenses/by/4.0/), which permits use, sharing, adaptation, distribution and reproduction in any medium or format, as long as you give appropriate credit to the original author(s) and the source, provide a link to the Creative Commons license and indicate if changes were made.

The images or other third party material in this chapter are included in the chapter's Creative Commons license, unless indicated otherwise in a credit line to the material. If material is not included in the chapter's Creative Commons license and your intended use is not permitted by statutory regulation or exceeds the permitted use, you will need to obtain permission directly from the copyright holder.

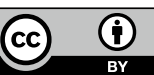

